\title{
TELAAH KRITIS PEMIKIRAN EKONOMI ISLAM TERHADAP MEKANISME PASAR DALAM KONTEKS EKONOMI ISLAM KEKINIAN
}

\author{
Oleh: Ulfa Jamilatul Farida ${ }^{1}$
}

\begin{abstract}
This article was aimed to explain the nature of market mechanism in Islamic economic thought as well as its practice in current days. Historical dan philosophical approach were used in the analysis to oversee Islamic basic teaching on market and to explore ideas and insights of muslim scholars regarding the subject. The article concluded that within Islamic framework, market mechanism has been regarded as important part of economic activities so that its existence has been main concern of many scholars. Market mechanism that protect people of the right and just price has also been considered as important and neccesary for better life. This then implied the need to keep market mechanism work which was part of government duties.
\end{abstract}

Keywords: market mechanism, government intervention, Ghazali, Ibn Taimia

\section{PENDAHULUAN}

Ilmu ekonomi Islam adalah suatu ilmu yang tumbuh dan menjadi gerakan perekonomian Islam sejak seperempat abad yang lalu.Selanjutnya, sebagaimana kita ketahui bahwa sistem yang menjadi hegemon pasca runtuhnya peradaban Islam adalah kapitalisme dimana hampir semua bidang kehidupan dipengaruhi filsafat kapitalisme. Dan pada suatu titik sudah tampak bahwa kapitalisme mulai runtuh dan menjadi penyakit perekonomian dunia, sehingga sekiranya terapi apa yang cocok untuk mengatasi krisis global ini. Ekonomi Islam yang mulai berkembang kembali menjadi solusi atas masalah-masalah tersebut. Bangunan ekonomi Islam yang berlandaskan Alquran dan Hadis dimana orientasi terwujudnya perekonomian yang berkeadilan sosial menjadi solusi.

Dalam ranah keilmuan ekonomi Islam bukan hal yang baru namun sempat mengalami kemunduran seiring peradaban dunia, sehingga bidang-bidang kajian keilmuan ekonomi Islam masih sangat luas dan untuk memudahkan tentu saja bidang kajian hampir sama dengan apa yang ada dalam ekonomi konvensional.Salah satu bidang kajian ekonomi Islam yang menarik untuk dibahas adalah mengenai pasar atau mekanisme pasar dalam konteks ekonomi Islam.

${ }^{1}$ Alumni Program Studi Hubungan Internasional Fisipol Universitas Muhammadiyah Yogyakarta, Program Studi Akhwalus Syakhsiyah Fakultas Syariah Universitas Islam Negeri Sunan Kalijaga Yogyakarta, dan Magister Studi Islam, Program Pascasarjana, Fakultas Ilmu Agama Islam, Universitas Islam Indonesia. E-mail: ulfa_faiz@yahoo.com. 
Ulfa Jamilatul Farida: Telaah Kritis Pemikiran Ekonomi Islamterhadap Mekanisme Pasardalam...

Pasar adalah tempat untuk beraktifitas ekonomi dimana kegiatan ekonomi berlangsung secara alamiah sehingga aturan mainnya pun terjadi secara alamiah. Namun demikian mengingat sifat manusia ada yang baik dan buruk dan perkembangan zaman, juga ideologi, maka pasar tidak lagi dapat dianggap sederhana, sehingga pembahasan mekanisme pasar menjadi penting. Sejarah mencatat pasar adalah tempat aktifitas ekonomi sehingga dari pasar inilah kita akan melihat bagaimana mekansime Islam menjadi dasar aktifitasnya?

\section{PENGERTIAN MEKANISME PASAR DALAM EKONOMI ISLAM}

Berbicara mengenai mekanisme pasar dalam dasar hukum Islam yang pertama yaitu al Qur'an, tentu saja al Qur'an sebagai dasar filosofi hidup manusia tidak memberikan atura secara jelas tentang apa itu mekanisme pasar. Namun demikian sebagai manusia yang dilengkapi akal maka kita akan dapatkan aturan main tentang pasar yaitu seperti apa yang tersebut dalam al Qur'an surat An-Nisa (4) ayat 29, sebagai berikut:

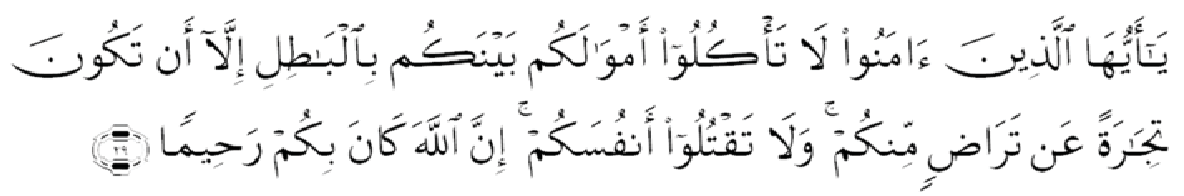

Artinya: Hai orang-orang yang beriman, janganlah kamu saling memakan harta sesamamu dengan jalan yang batil, kecuali dengan jalan perniagaan yang Berlaku dengan suka sama-suka di antara kamu. dan janganlah kamu membunuh dirimu²; Sesungguhnya Allah adalah Maha Penyayang kepadamu.(29)

M. Quraish Shihab dalam tafsirnya al-Misbah menafsirakan ayat tersebut (QS. An-Nisa (4): 29) sebagai berikut. Dalam konteks ekonomi, ayat tersebut menyebutkan beberapa prinsip penting dalam berekonomi. Pertama adalah kata

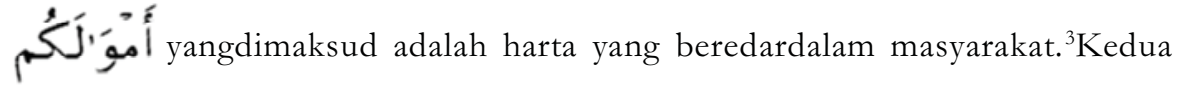

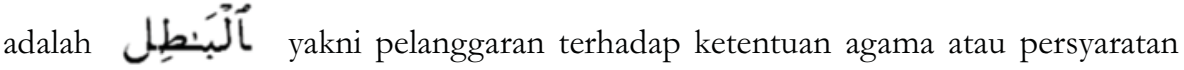
yang disepakati. Dalam konteks ini, Nabi Muhammad saw. Bersabda, "Kaum muslimin sesuai dengan (harus menepati) syarat-syarat yang mereka sepakati, selama tidak menghalalkan yang haram atau mengharamkan yang halal". ${ }^{4}$ Dan selanjutnya

\footnotetext{
${ }^{2}$ Larangan membunuh diri sendiri mencakup juga larangan membunuh orang lain, sebab membunuh orang lain berarti membunuh diri sendiri, karena umat merupakan suatu kesatuan.

${ }^{3}$ M. Quraish Shihab, Tafsir al Misbah (Jakarta: Lentera Hati, 2002), h. 412.

${ }^{4}$ Ibid., hal. 413
} 
adalah kata yang mengharuskan adanya kerelaan kedua belah pihak yaitu prinsip 'an taradhin minkum. Walaupun kerelaan adalah hal yang tersembunyi di dalam hati, tetapi indikator dan tanda-tandanya dapat terlihat. Ijab dan kabul, atau apa saja yang dikenal dalam adat kebiasaan sebagai serah terima adalah bentuk-bentuk yang digunakan hukum untuk menunjukkan kerelaan. ${ }^{5}$

Dari tafsir ayat an Nisa (4):29 tersebut jelas apa yang menjadi prinsip dasar aktifitas pasar. Selanjunya bagaimana pasar atau mekanisme pasar pada masa Nabi?

\section{A. Pasar pada masa Rasulullah Muhammad saw.}

Pasar memegang peranan penting dalam perekonomian masyarakat Muslim pada masa Rasulullah SAW dan Khulafaurrasyidin. Bahkan, Muhammad SAW sendiri pada awalnya adalah seorang pebisnis, demikian pula Khulafaurrasyidin dan kebanyakan sahabat. Pada saat awal perkembangan Islam di Makkah Rasulullah SAW dan masyarakat Muslim mendapat gangguan dan terror yang berat dari masyarakat kafir Makkah sehingga perjuangan dan dakwah merupakan prioritas. Ketika masyarakat Muslim telah berhijrah ke Madinah, peran Rasulullah SAW bergeser menjadi pengawas pasar atau $A l$ - mubtasib.

Pada saat itu mekanisme pasar sangat dihargai. Beliau menolak untuk membuat kebijakan penetapan harga manakala tingkat harga di Madinah pada saat itu tiba-tiba naik. Sepanjang kenaikan terjadi karena kekuatan permintaan dan penawaran yang murni, yang tidak dibarengi dengan dorongan-dorongan monopilistik dan monopsonistik, maka tidak ada alasan untuk tidak menghormati harga pasar. Dalam suatu Hadits dijelaskan bahwa pasar merupakan hukum alam (Sunnatullah) yang harus dijunjung tinggi. Tak seorang pun secara individual dapat mempengaruhi pasar, sebab pasar adalah kekuatan kolektif yang telah menjadi ketentuan Allah SWT.

Pelanggaran terhadap harga pasar, misalnya penetapan harga dengan cara dan karena alasan yang tidak tepat, merupakan suatu ketidakadilan (injustice) yang akan dituntut pertanggung jawabannya dihadapan Allah dan begitu pun sebaliknya.Penghargaan Islam terhadap mekanisme pasar berdasar pada ketentuan Allah SWT bahwa perniagaan harus dilakukan secara baik dengan rasa suka sama suka serta nilai moralitas mutlak harus ditegakkan. Secara khusus nilai moralitas yang mendapat perhatian penting dalam pasar adalah persaingan yang sehat, kejujuran, keterbukaan, dan keadilan.

\section{B. Pasar dalam Perspektif Pemikir Muslim}

\section{Mekanisme Pasar Menurut Abu Yusuf (731-798 M)}

Pemikiran Abu Yusuf tentang pasar dapat dijumpai dalam bukunya $A$ l-Kharaj yang membahas prinsip-prinsip perpajakan dan anggaran negara yang menjadi 
pedoman Kekhalifahan Harun Al-Rasyid di Baghdad. Ia menyimpulkan bekerjanya hukum permintaan dan penawaran pasar dalam menentukan tingkat harga, meskipun kata permintaan dan penawaran ini tidak ia katakana secara eksplisit. Selain itu dalam bukunya secara implisit juga dijelaskan bahwa, harga bukan hanya ditentukan oleh penawaran saja, tetapi juga permintaan terhadap barang tersebut. Bahkan, Abu Yusuf mengidikasikan adanya variable-variabel lain yang juga turut mempengaruhi harga, misalnya jumlah uang beredar di Negara itu, penimbunan atau penahanan suatu barang, atau lainnya. ${ }^{6}$

\section{Evolusi Pasar Menurut Al-Ghazali (1058-1111 M) ${ }^{7}$}

Al-Ihya Ulumuddin karya Al-Ghazali banyak membahas topik-topik ekonomi, termasuk pasar. Dalam karyanya tersebut ia membicarakan barter dan permasalahannya, pentingnya aktivitas perdagangan dan evolusi terjadinya pasar, termasuk bekerjanya kekuatan permintaaan dan penawaran dalam mempengaruhi harga. Al-Ghazali menyadari kesulitan yang timbul akibat sistem barter yang dalam istilah ekonomi modern disebut double coincidence, dan karena itu diperlukan suatu pasar. Selain itu Al-Ghazali juga telah memahami suatu konsep, yang sekarang kita sebut elastisitas permintaan. Hal ini tampak jelas dari perkataaannya bahwa mengurangi margin keuntungan dengan menjual harga yang lebih murah akan meningkatkan volume penjualan, dan ini pada gilirannya akan meningkatkan keuntungan.

\section{Pemikiran Ibn Taimiyah ${ }^{8}$}

Pemikiran Ibn Taimiyah mengenai mekanisme pasar banyak dicurahkan melalui bukunya, yaitu Al-Hisbah fi'l Al-Islam dan Majmu' Fatawa. Pandangan Ibn Taimiyah mengenai hal ini sebenarnya terfokus pada masalah pergerakan harga yang terjadi pada waktu itu, tetapi ia letakan dalam kerangka mekanisme pasar. Secara umum, beliau telah menunjukanthe beauty of market(keindahan mekanisme pasar sebagai mekanisme ekonomi). Beberapa faktor yang mempengaruhi permintaaan dan kemudian tingkat harga adalah sebagai berikut:

- Keinginan orang terhadap barang-barang sering kali berbeda-beda.

- Jumlah orang yang meminta.

- Kuat atau lemahnya kebutuhan terhadap barang-barang itu.

${ }^{6}$ Lihat Abu Yusuf ibn Ya'qub ibn Ibrahim, (1979), Kitab al-Kharaj, (Beirut: Dar alMa'rifah li ath-Thiba'ah wa an-Nasyr) atau lihat Abul Hasan M. Sadeq dan Aidit Ghazali (eds.), (1992), Readings in Islamic Economic Thought (Malaysia: Longman Malaysia, hh. 15-16.

${ }^{7}$ Abul Hasan M. Sadeq, "al-Ghazali on Economic Issues and Some Ethico-Juristic Matters Having Implications for Economic Behaviour", dalam Abul Hasan M. Sadeq dan Aidit Ghazali (Ed), Readings in Islamic Economic Thought (Malaysia: Longman Malaysia), hh. 95-96.

8، Abdul Azim Islahi, "Economics Consepts of Ibn Taimiyyah", dalam Ibid., hh. 126-129. ${ }^{9}$ Ibid. 
Ulfa Jamilatul Farida: Telaah Kritis Pemikiran Ekonomi Islamterhadap Mekanisme Pasardalam...

- Kualitas pembeli baranng tersebut.

- Jenis (uang) pembayaran yang digunakan dalam transaksi jual beli.

Ibn Taimiyah secara umum sangat menghargai arti penting harga yang terjadi karena mekanisme pasar yang bebas. Ia menolak segala campur tangan untuk menekan atau menetapkan harga sehingga mengganggu mekanisme yang bebas.

\section{Mekanisme Pasat Menurut Ibn Khaldun (1332-1383 M)}

Ibn Khaldun sangat menghargai harga yang terjadi dalam pasar bebas, namun ia tidak mengajukan saran-saran kebijakan pemerintah untuk mengelola harga. Ia lebih banyak memfokuskan kepada faktor-faktor yang mempengaruhi harga. Hal ini tentu saja berdeda dengan Ibn Taimiyah yang dengan tegas menentang intervensi pemerintah sepanjang pasar berjalan dengan bebas dan normal. ${ }^{10}$

\section{KEKUATAN PASAR DALAM EKONOMI ISLAM}

Pasar adalah sebuah mekanisme pertukaran barang dan jasa yang alamiah dan telah berlangsung sejak peradaban awal manusia. Islam menempatkan pasar pada kedudukan yang penting dalam perekonomian. Praktik ekonomi pada masa Rasulullah dan Khullafaurrasyidin menunjukan adanya peranan pasar yang besar. Rasulullah sangat menghargai harga yang dibentuk oleh pasar sebagai harga yang adil.

Beliau menolak adanya suatu price intervention seandainya perubahan harga terjadi karena mekanisme pasar yang wajar. Namun, pasar di sini mengharuskan adanya moralitas, anatara lain: persaingan yang sehat (fair play), kejujuran (honesty), keterbukaan (transparancy), dan keadilan (justice). Jika nilai-nilai ini telah ditegakkan, maka tidak ada alasan untuk menolak harga pasar. ${ }^{11}$

Catatan sejarah memaparkan bagaimana Rasulullah menghargai mekanisme pasar sebagai sebuah sunnatullah yang harus dihormati. Pandangan tentang pasar dan harga dari beberapa pemikir besar muslim seperti Abu Yusuf, Al-Ghazali, Ibn Khaldun, Ibn Taimiyah juga diungkap. Pemikiran-pemikiran mereka tentang pasar ternyata sangat canggih dan tergolong futuristik jika dipandang pada masanya. Pemikiran-pemikran mereka tentu saja merupakan kekayaan khasanah intelektual yang sangat berguna pada masa kini dan masa depan. Selanjutnya dipaparkan bagaimana mekanisme kerja pasar serta faktor-faktor yang memengaruhinya. Beberapa bentuk transaksi bisnis yang dianggap tidak Islami yang umum dipraktikan masyarakat Arab pada waktu itu. Berikut akan dipaparkan mekanisme pasar sebagaimana dikonsepkan para pemikir Islam Klasik:

${ }^{10}$ Charles Issawi, "Ibn Khladun's Analysis of Economics Issues", dalam Ibid., hal. 232-233

${ }^{11}$ Disarikan dari MM. Metwally, (1995), Teori dan Model Ekonomi Islam, (Jakarta: PT. Bangkit Daya Insana), hh. 1-6. 
Ulfa Jamilatul Farida: Telaah Kritis Pemikiran Ekonomi Islamterhadap Mekanisme Pasardalam...

\section{A. Permintaaan}

Permintaan merupakan salah satu elemen yang menggerakan pasar. Istilah yang digunakan oleh Ibn Taimiyah untuk menunjukan permintaan ini adalah keinginan. Pada dasarnya faktor-faktor yang mempengaruhi permintaaan sebagai berikut: ${ }^{12}$

\section{Faktor-faktor penentu permintaan}

\section{a. Harga barang yang bersangkutan}

Pada umumnya hubungan antara tingkat harga dan jumlah permintaan adalah negatif, yakni semakin tinggi tingkat harga, maka semakin rendah jumlah permintaan, demikian pula sebaliknya.

\section{1).Efek Substitusi}

Efek subtitusi berarti bahwa jika harga suatu barang naik, maka hal ini akan mendorong konsumen untuk mencari barang lain yang bias menggantikan fungsi dari barang yang harganya naik tersebut (barang subtitusi).

\section{2).Efek Pendapatan}

Efek pendapatan berarti bahwa, jika harga suatu barang naik maka berarti pula secara riil pendapatan konsumen turun sebab dengan pendapatan yang sama ia hanya dapat membeli barang sedikit.

\section{b. Pendapatan Konsumen}

Semakin tinggi pendapatan seorang konsumen, maka akan semakin tinggi daya belinya sehingga permintaannya terhadap barang akan semakin meningkat pula.

\section{c. Harga barang lain yang terkait}

Yang dimaksud barang lain yang terkait adalah subtitusi dan komplementer dari barang tersebut. Jika harga barang subtitusinya turun, maka permintaan terhadap barang tersebut pun turun, sebab konsumen mengalihkan pada barang subtitusi. Sementara jika barang komplementernya naik, maka permintaan terhadap barang tersebut akan turun.

${ }^{12}$ Lihat 'Abdul Azim Islahi, "Economics Consepts of Ibn Taimiyyah", dalam Abul Hasan M. Sadeq dan Aidit Ghazali (eds.), (1992), Readings in Islamic Economic Thought (Malaysia: Longman Malaysia). Lihat Veithzal Rivai dan Andi Buchari, (2009), Islamic Economics: Ekonomi Syariah Bukan Opsi, Tetapi Solusi, (Jakarta: Bumi Aksara), hh. 374-377. 
Ulfa Jamilatul Farida: Telaah Kritis Pemikiran Ekonomi Islamterhadap Mekanisme Pasardalam...

\section{d. Selera konsumen}

Jika selera konsumen terhadap barang tersebut tinggi maka permintaannya pun akan tinggi meskipun harganya pun tinggi, dan begitu pun sebaliknya.

\section{e. Ekspektasi (pengharapan)}

Meskipun tidak secara eksplisit, pemikiran ekonomi Islam klasik telah menengarai peran ekspektasi dala menentukan permintaan. Ekspektasi bias berupa ekspektasi positif maupun negative. Dalam kasus ekspektasi positif konsumen akan lebih terdorong untuk membeli suatu barang, dan untuk ekspektasi negative berlaku sebaliknya.

\section{f. Mashlahah}

Pengaruh mashlahah terhadap permitaan tidak bisa dijelaskan secara sederhana sebab ini tergantung kepada tingkat keimanan. Jika maslahah relative turun maka jumlah barang yang diminta akan turun juga, begitu juga sebaliknya.

\section{B. Penawaran ${ }^{13}$}

Dalam khasanah pemikiran ekonomi Islam Klasik, pasokan (penawaran) telah dikenal sebagai kekuatan penting di dalam pasar. Ibn Taimiyah mengistilahkan penawaran ini sebagai ketersediaaan barang di pasar.

\section{Mashlahah}

Pengaruh mashlahah terhadap penawaran pada dasarnya akan tergantung pada tingkat keimanan produsen. Jika jumlah mashlahah yang terkandung dalam barang yang diproduksi semakin meningkat, maka produsen Muslim akan memperbanyak jumlah produksinya.

\section{Keuntungan}

Keuntungan merupakan bagian dari mashlahah karena ia dapat mengakumulasi modal pada akhirnya dapat digunakan berbagai aktivitas lainnya. Faktor-faktor yang mempengaruhi keuntungan adalah:

\section{a. Harga Barang}

Jika harga suatu barang naik maka keuntungan akan naik pula. Kemudian hal ini akan menaikan total keuntungan sehingga mendorong produsen untuk melakukan penawaran lebih naik lagi.

\footnotetext{
${ }^{13} \mathrm{Ibid}$.
} 
Ulfa Jamilatul Farida: Telaah Kritis Pemikiran Ekonomi Islamterhadap Mekanisme Pasardalam...

\section{b. Biaya Produksi}

Biaya produksi jelas menentukan tingkat keuntungan sebab keuntungan merupakan selisih dari penerimaan dengan biaya produksi. Jika biaya turun maka keuntungan produsen akan meningkat, dan hal ini akan mendorongnya untuk meningkatkan penawaran.

\section{IV.PERMASALAHAN DALAM PENERAPAN MEKANISME PASARPERSPEKTIF ISLAM}

Berbicara mengenai masalah mekanisme pasar maka pertanyaan yang muncul tentu masalah keseimbangan dalam pasar. Keseimbangan atau ekuilibrium menggambarkan suatu situasi dimana semua kekuatan yang ada dalam pasar, permintaan dan penawaran, berada dalam keadaan seimbang sehingga setiap variabel yang terbentuk di pasar, harga dan kuantitas sudah tidak lagi berubah. Dalam keadaan ini harga dan kuantitas yang diminta akan sama dengan yang ditawarkan sehingga terjadilah transaksi. Selanjutnya, proses terjadinya keseimbangan dalam pasar dapat berawal dari sisi mana saja, baik dari permintaan ataupun penawaran. Adapun perubahan keseimbangan dapat melalui:

- Perubahan Berasal dari Sisi Permintaan

- Perubahan Berasal dari Sisi Penawaran

- Perubahan Berasal dari Sisi Penawaran dan Permintaan

Ketika berbicara mengenai kesempurnaan pasar maka berikutnya adalah kondisi ketidaksempurnaan bekerjanya pasar. Ketidaksempurnaan pasar dapat dipicu oleh beberapa hal yaitu sebagai berikut: ${ }^{14}$

\section{A. Penyimpangan Terstruktur}

Struktur atau bentuk organisasi pasar akan mengganggu mekanisme pasar dengan cara yang sistematis dan terstruktur pula. Struktur pasar yang dimaksud adalah monopoli, duopoly, oligopoly, dan kompetisi monopolistik. Misalnya saja dalam monopoli, produsen monopolis bisa saja mematok harga yang tinggi untuk memperoleh keuntungan di atas normal, demikian pula untuk pasar yang lain.

\section{B. Penyimpangan Tidak Terstruktur}

Selain itu juga terdapat faktor-faktor yang incidental dan temporer yang mengganggu mekanisme pasar. Beberapa contohnya adalah usaha sengaja menimbun untuk menghambat pasokan barang agar harga pasar naik (ikhtikar), penciptaan permintaan semu untuk menaikan harga (najasyz), penipuan kualitas, kuantitas, harga,

14 Adiwarman A. Karim, (2007), Ekonomi Mikro Islami, Ed. 3, (Jakarta: Raja Grafindo Persada), hh. 162-163. 
Ulfa Jamilatul Farida: Telaah Kritis Pemikiran Ekonomi Islamterhadap Mekanisme Pasardalam...

atau waktu pengiriman (tadlis), kolusi para pedagang untuk membuat harga di atas normal (bai al-hadir lil badi), dan lain-lain.

\section{Ketidaksempurnaan Informasi dan Penyesuaian}

Ketidaksempurnaan pasar juga disebabkan karena ketidaksempurnaan informasi yang dimiliki para pelaku pasar. Informasi merupakan hal yang penting sebab ia menjadi dasar bagi pembuatan keputusan. Rasulullah melarang berbagai transaksi yang terjadi dalam ketidaksempurnaan informasi, missal menghalangi transaksi pada harga pasar, mengambil keuntungan yang tinggi dengan memanfaaatkan kebodohan konsumen, dan lain-lain.

Dalam praktik pasar tersebut secara prinsip pokok masalahnya adalah ketika terjadi ketidaksempurnaan pasar atau penyimpangan dan kemudian bagaimana Islam melihat kondisi seperti ini. Ajaran Islam memberi perhatian yang besar terhadap kesempurnaan mekanisme pasar. Pasar yang bersaing sempurna menghasilkan harga yang adil bagi penjual dan pembeli. Karenanya jika mekanisme pasar terganggu, maka harga yang adil tidak dapat dicapai, begitu pun sebaliknya.

\section{Harga yang Adil dalam Islam}

Harga yang adil ini dijumpai dari beberapa terminologi, anatara lain: si'r almithl, thaman al-mithl, dan qimah al-adl. Ibn Taimiyah mendefinisikan harga yang adil itu adalah harga baku diman penduduk menjual barang-barang mereka dan secara umum diterima sebagai sesuatu yang setara dengan itu dan untuk barang yang sama pada waktu dan tempat yang khusus. ${ }^{15}$

Sedangkan dalam Al-Hisbah ia mengatakan bahwa equivalen prince ini sesuai dengan keinginan atau harga yang ditetapkan oleh kekuatan pasar yang berjalan secara bebas dan kompetitif.

\section{Solusi Islam terhadap Ketidaksempurnaan Bekerjanya Pasar}

\section{a. Larangan Ikhtikar}

Rasulullah telah melarang praktek ikhtikar, yaitu secara sengaja menahan atau menimbun barang, terutama pada saaat terjadinya kelangkaan, dengan tujuan untuk menaikan harga di kemudian hari. Akibat dari ikhtikar ini masyarakat luas akan dirugikan oleh sekelompok kecil yang lain. Agar harga dapat kembali ke posisi semula maka pemerintah dapat melakukan berbagi upaya menghilangkan penimbuanan ini. Namun tidak termasuk ikhtikar adalah penumpukan yang dilakukan pada situasi ketika pasokan melimpah, misalnya penimbunan atau penahanan pada saat panen besar, dan segera menjualnya pada saat pasar membutuhkan.

\footnotetext{
${ }^{15}$ Ibid., hal. 164.
} 
Ulfa Jamilatul Farida: Telaah Kritis Pemikiran Ekonomi Islamterhadap Mekanisme Pasardalam...

\section{b. Membuka Akses Informasi}

Beberapa larangan terhadap praktik penipuan pada dasarnya adalah upaya untuk menyebarkan keterbukaan informasi sehingga transaksi dapat dilakukan dengan sama-sama suka dan adil. Beberapa larangan ini antara lain: talaqi rukbban (membeli barang dengan cara mencegat para penjual di luar kota), bay najasyi (mencakup pengertian kolusi dimana antarpenjual satu dengan yang lainnya melakukan kerja samauntuk menipu konsumen), ghaban fahisy (upaya sengaja untuk mengaburkan informasi sebab penjual memanfaatkan ketidaktahuan konsumen untuk mencari keuntungan yang tinggi.

\section{c. Regulasi Harga}

Pada dasarnya jika pasar sudah bekerja dengan sempurna, maka tidak ada alas an untuk mengatur tingkat harga. Penetapan harga justru akan mendistorsi harga sehingga akhirnya mengganggu mekanisme pasar itu sendiri. Jadi regulasi harga dapat dilakukan pada situasi tertentu saja. Pemerintah dapat melakuakan regulasi harga apabila pasar bersaing tidak sempurna, dan keadaan darurat. Apabila terpaksa menentapkan harga, maka konsep harga yang adil harus menjadi pedoman. Adapun beberapa keadaan darurat diantaranya adalah harga naik sedemikian tinggi di kuar kewajaran, menyangkut barang-barang yang amat dibutuhkan masyarakat, terjadi ketidakadilan.

\section{TELAAH KRITIS MEKANISME PASAR ISLAM ANTARA IDEALITA DAN REALITA}

Dalam ekonomi konvensional, Adam Smith dalam the Wealth of Nation:

"Dengan cara mengarahkan produksi, hal ini dapat menggerakkan produksi yang mampu menghasilkan nilai yang paling besar, padahal dia hanya meniatkannya untuk keuntungan dirinya sendiri, dan yang demikian, digerakkan oleh tangan yang tak kentara yang mengarahkannya kepada batas yang tidak ia kehendaki." 16

Secara singkat Smith mengungkapkan bahwa walaupun setiap orang mengerjakan sesuatu didasarkan kepada kepentingan pribadi, tetapi hasilnya akan lebih efektif dan selaras dengan tujuan masyarakat. Dampak aktivitas setiap individu dalam mengejar kepentingannya masing masing terhadap kemajuan masyarakat, justru lebih baik dibanding dengan tiap orang berusaha untuk memajukan masyarakat. Niat baik pemerintah untuk mensejahterakan masyarakat seringkali berbanding terbalik dengan realita yang terjadi.Filosofi Adam Smith tersebut menjadi akar perkembangan ilmu ekonomi konvensional termasuk bidang kajian mekanisme pasar.

${ }^{16}$ Adam Smith, (1937), An Inquiry Into The Nature and Causes of the Wealth of Nations, (New York: The Modern Library). 
Ulfa Jamilatul Farida: Telaah Kritis Pemikiran Ekonomi Islamterhadap Mekanisme Pasardalam...

Filosofi Smith ini selanjutnya mendapat kritik tajam dari Marx karena ideide Smith hanya akan menguntungkan pemilik modal dan memunculkan sistem kelas. Marx merupakan penentang keras dari mekanisme pasar bebas yang diungkapkan oleh Adam Smith. Ada tiga hal yang menjadi alasannya: ${ }^{17}$

1. Dalam ekonomi. Laissez faire mendorong adanya surplus value dan penguasaan kekayaan oleh segelintir orang. Buruh diperas tenaganya dengan upah minimum.

2. Dalam psikologi. Menimbulkan adanya pertentangan antara kelas tuan tanah dan buruh

3. Dalam sosial. Masyarakat terpecah menjadi kelas tuan tanah dan buruh.

Namun demikian, hampir semua jatuh bangunnya paradigma ekonomi konvensional ini senantiasa tidak dapat menawarkan sebuah tatanan yang benarbenar berkeadilan dan menjunjung nilai-nilai etika berekonomi yang luhur sehingga semuanya bersifat parsial mengingat orientasinya yang keduniaan saja.

Ketika ekonomi kapitalisme telah menjadi hegemoni sekian lama, dan telah menjadi penjajah ekonomi dunia termasuk didalamnya negara-negara muslim maka pada satu titik telah mengalami kehancuran. Runtuhnya kapitalisme ini tidak serta merta membuat sistem ini hilang atau tidak dipergunakan lagi, mengingat sistem ini telah mengilhami sistem dunia yang kompleks sehingga tidak mudah bagi sistem ekonomi Islam mengubahnya dan penting menentukan tahapan-tahapan strategisnya.

Dalam konteks mekanisme pasar, secara ideal Islam dapat dirujuk dari apa yang dijelaskan oleh Ibn Taimiyah. Ibnu Taimiyah berkata: ${ }^{18}$

"Naik dan turunnya harga tak selalu berkait dengan kezaliman (zulm) yang dilakukan seseorang. Sesekali, alasannya adalah adanya kekurangan dalam produksi atau penurunan impor dari barang-barang yang iminta. Jadi, jika membutuhkan peningkatan jumlah barang, sementara kemampuannya menurun, harga dengan sendirinya akan naik. Di sisi lain, jika kemampuan penyediaan barang menigkat dan permintaannya menurun, harga akan turun. Kelangkaan dan kelimpahan tak mesti diakibatkan oleh perbuatan seseorang. Bisa saja berkaitan dengan sebab yang tak melibatkan ketidakadilan. Atau, sesekali, bisa juga disebabkan ketidak adilan. Maha Besar Allah, yang menciptakaan kemauan pada hati manusia...”.(Ibnu Taimiyah, Majmu' fatawa).

Ungkapan ini menunjukkan bahwa ada kebiasaan yang berlaku di zaman ibnu Taimiyah bahwa kenaikan harga seringkali diakibatkan oleh ketidakadilan para pelaku pasar. Pandangan ini ditolak oleh ibnu Taimiyah dengan mengungkapkan

${ }^{17}$ Lihat Deliarnov, (2006), Ekonomi Politik: Mencakup Berbagai Teori dan Konsep yang Komprehensif, (Jakarta: Erlangga).

${ }^{18}$ Lihat'Abdul Azim Islahi, "Economics Consepts of Ibn Taimiyyah", dalam Abul Hasan M. Sadeq dan Aidit Ghazali (eds.), (1992), Readings in Islamic Economic Thought (Malaysia: Longman Malaysia), h. 126. 
Ulfa Jamilatul Farida: Telaah Kritis Pemikiran Ekonomi Islamterhadap Mekanisme Pasardalam...

bahwa kenaikan harga tidak selamanya disebabkan zulm (ketidakadilan). Ada faktor lain yang mempengaruhinya yakni kekuatan pasar antara supply dan demand.

Dalam kitab Fatawa. Ibnu Taimiyah menjelaskan faktor-faktor yang mempengaruhi permintaan: (ekonomi Islam) dan konsekuensinya terhadap harga: ${ }^{19}$

1. Ar-Raghabab (keinginan) atas barang-barang berbeda dan seringkali berubah. Hal ini turut dipengaruhi oleh berlimpah atau langkanya suatu barang. Semakin langka semakin ia diminati oleh masyarakat. Dalam konvensional faktor ini dikenal dengan istilah preference (minat).

2. Jumlah orang yang meminta. Semakin banyak orang yang meminta dalam satu jenis barang dagangan, maka semakin mahal harga barang.

3. Kuat atau lemahnya permintaan. Kebutuhan tinggi dan kuat, harga akan naik lebih tinggi ketimbang jika peningkatan kebutuhan itu kecil atau lemah.

4. Kualitas pembeli (al-mu'awid). Harga juga berubah-rubah, sesuai dengan siapa saja transaksi tersebut dilakukah. Pembeli yang memiliki kredibilitas yang buruk, sering bankrut, mengulur-ulur pembayaran akan mendaoatkan harga yang lebih tinggi dari pembeli yang memiliki predikat baik.

5. Jenis uang yang digunakan. Harga juga dipengaruhi oleh bentuk alat pembayaran (uang) yang digunakan dalam jual beli. Jika yang digunakan adalah naqd raji, harga akan lebih rendah ketimbang membayar dengan uang yang jarang ada di peredaran.

6. Hal diatas dapat terjadi karena tujuan dari suatu transaki harus menguntungkan penjual dan pembeli. Jika pembeli memiliki kemampuan untuk membayar dan dapat memenuhi janjinya, maka transaksi akan lebih mudah/lancar.

Aplikasi yang sama berlaku bagi sesorang yang meminjam atau menyewa. Adanya biaya tambahan akan mengakibatkan perubahan harga. Menyewa tanah dalam kondisi banyaknya perampok atau hewan liar akan menambah beban bagi penyewa, sehingga harga sewa lebih rendah dibanding tanah yang tidak membutuhkan biaya tambahan.

Kemudian mengenai penetapan (regulasi) harga dikenal dalam dunia fiqih dengan istilah tas'ir yang berarti, menetapkan harga tertentu pada barang-barang yang diperjualbelikan dimana tidak mendzalimi pemilik barang dan pembelinya. ${ }^{20}$ Dalam konsep ekonomi Islam penentuan harga dilakukan oleh kekuatan-kekuatan pasar yaitu kekuatan permintaan dan penawaran. Dalam konsep Islam, pertemuan permintaan dengan penawaran tersebut haruslah terjadi secara rela sama rela, dalam artian tidak ada pihak yang terpaksa untuk melakukan transaksi pada tingkat harga tertentu. Keadaan rela sama rela merupakan kebalikan dari keadaan aniaya yaitu keadaan dimana salah satu pihak senang diatas kesedihan pihak lainnya. Dalam hal

${ }^{19}$ Ibid., h. 127.

${ }^{20}$ Sayyid Sabiq, (1995), Fiqhus Sunnah, (Beirut: Syirkatu Manar ad-Dauliyah). 
Ulfa Jamilatul Farida: Telaah Kritis Pemikiran Ekonomi Islamterhadap Mekanisme Pasardalam...

harga, para ahli fiqih merumuskannya sebagai the price of the equivalent (Tsamanul Mitsly).

Selanjutnya bagaimana jika sistem Islam diterapkan namun terjadi penyimpangan dari kondisi normal? Menurut Islam negara memiliki hak untuk melakukan intervensi dalam kegiatan ekonomi baik itu dalam bentuk pengawasan, pengaturan maupun pelaksanaan kegiatan ekonomi yang tidak mampu dilaksanakan oleh masyarakat. Intervensi harga oleh pemerintah bisa karena faktor alamiah maupun non alamiah. Intervensi dengan cara membuat kebijakan yang dapat mempengaruhi dari sisi permintaan maupun dari sisi penawaran (market intervention) biasanya dikarenakan distorsi pasar karena faktor alamiah. Bila distorsi pasar terjadi karena faktor non almiah, maka kebijakan yang ditempuh salah satunya dengan dengan intervensi harga di pasar. Dengan segala kebijakannya untuk mengatur, negara sangat berwenang untuk mengatur dengan orientasi demi kemaslahatan umat.

Demikian paparan bagaimana sistem ekonomi Islam mempunyai tatanan mengenai mekanisme pasar. Adalah sebuah harapan sistem ini dapat berjalan secara ideal sehingga kesenjangan ekonomi dapat diminimalisir.

\section{PENUTUP}

Pasar adalah tempat untuk beraktifitas ekonomi dimana kegiatan ekonomi berlangsung secara alamiah sehingga aturan mainnya pun terjadi secara alamiah. Sehingga menurut ekonomi Islam mekanisme pasar dapat terjadi secara alamiah dari sisi penawaran dan permintaan sebagaimana mestinya. Selanjutnya dalam hal mekanisme pasar perspektif ekonomi Islam pada prinsipnya adalah menolak adanya suatu price intervention seandainya perubahan harga terjadi karena mekanisme pasar yang wajar. Namun, pasar di sini mengharuskan adanya moralitas, anatara lain: persaingan yang sehat (fair play), kejujuran (bonesty), keterbukaan (transparancy), dan keadilan (justice). Jika nilai-nilai ini telah ditegakkan, maka tidak ada alasan untuk menolak harga pasar. Dan jika terjadi penyimpangan maka kewajiban negara untuk mengaturnya demi kemaslahatan umat.

\section{DAFTAR PUSTAKA}

Deliarnov (2006), Ekonomi Politik: Mencakup Berbagai Teori dan Konsep yang Komprehensif. Jakarta: Erlangga.

Ibrahim, Abu Yusuf ibn Ya'qub ibn (1979), Kitab al-Kharaj. Beirut: Dar al-Ma'rifah li ath-Thiba'ah wa an-Nasyr.

Adiwarman A. Karim (2007), Ekonomi Mikro Islami, Ed. 3. Jakarta: Raja Grafindo Persada.

Metwally, MM. (1995), Teori dan Model Ekonomi Islam. Jakarta: PT. Bangkit Daya Insana. 
Ulfa Jamilatul Farida: Telaah Kritis Pemikiran Ekonomi Islamterhadap Mekanisme Pasardalam...

M. Quraish Shihab (2002), Tafsir al-Misbah. Jakarta: Lentera Hati.

Sabiq, Sayyid (1995), Fiqhus Sunnah, Beirut: Syirkatu Manar ad-Dauliyah.

Sadeq, Abul Hasan M. dan Aidit Ghazali (eds.) (1992), Readings in Islamic Economic Thought. Kuala Lumpur: Longman Malaysia.

Smith, Adam (1937), An Inquiry Into The Nature and Causes of the Wealth of Nations. New York: The Modern Library.

Veithzal Rivai dan Andi Buchari (2009), Islamic Economics: Ekonomi Syariah Bukan Opsi, Tetapi Solusi. Jakarta: Bumi Aksara. 